\title{
Perceptions of Professors of Educational Inclusion: Diversity, Cooperation and Commitment
}

\author{
María José Alcalá del Olmo Fernández , María Jesús Santos Villalba, Juan José Leiva Olivencia \\ Faculty of Education Sciences, University of Malaga, Spain
}

Received May 5, 2020 ; Revised June 12, 2020; Accepted July 7, 2020

Copyright $\bigcirc 2020$ by authors, all rights reserved. Authors agree that this article remains permanently open access under the terms of the Creative Commons Attribution License 4.0 International License

\begin{abstract}
Educational inclusion represents a commitment to attend to diversity, based on accessible curricular structures able to respond to the needs of an increasingly diverse student body. In the Campaign Education to transform lives, promoted by Unesco, in addition to approving the 2030 Agenda, the 17 Sustainable Development Goals were specified, claiming the need for education systems to move towards inclusive education capable of eradicating discriminatory situations of distress and social injustice. Within the university, this challenge involves the formation of student-focused learning spaces, as shown by the results of several investigations, which recognize the commitment with the educational inclusion that the current university must assume. The purpose of this study has been to identify and understand the perceptions of education professionals at the University of Malaga in the implementation of the education committed to inclusion. Following a qualitative methodology, teachers from the Primary Education and Social Education Grades have participated, collecting information from semi-structured ad hoc interviews. The main contributions of this research in its field of study show that teachers have some difficulties in addressing educational inclusion, as they lack specific training. In addition to this, the professional sector considers itself responsible for offering a response to diversity, opting for innovative methodologies that help to overcome the barriers that prevent the increase of knowledge and that commit to promote shared learning experiences.
\end{abstract}

Keywords Higher Education, University Professor, Inclusive Education, Diversity

\section{Introduction}

In the European Higher Education framework, didactic intervention focuses on the student, which demands on the part of university professors, their commitment to adapt their professional profile to the needs of this new socio-educational scenario. According to this new approach, one of the main competences of university professors is the need to respond to diversity, regarded as mutual enrichment [1,2] and the need to acknowledge that all students are able to learn, which is important when working in didactic aspects, such as thought and intervention [3]. As a result of the above, over the last decades, the great influence of traditional medical models, in which differences were perceived as obstacles or barriers to learning, has been overcome to give way to models of an inclusive nature [4], in which the relevant thing is to decide the changes to be implemented in educational institutions, in order to offer an education of the highest possible quality and excellence.

In response to certain laws and policies, there are more and more higher education centers that have established support services to respond to students' needs, incorporating the use of technological tools and implementing inclusive pedagogical practices [5-10]. In addition, there is an increase in research focused on implementing an inclusive pedagogy at university, analyzing the attitudes of university professors towards educational inclusion and identifying the obstacles encountered by university students with functional diversity [11-22].

Authors such as Moriña [19], undertook a qualitative research to examine the degree of professors' responsibility in implementing an education that is able to promote a culture of inclusion, together with the most appropriate methodology to do so. The sample was made up of 119 university professors from 10 Spanish universities. Results showed that professors that are committed to educational inclusion at university prefer to use active methodologies, focused on students' needs and interests, offering ongoing feedback on learning. Likewise, addressing affective and emotional variables is seen as key to increase motivation and ensure functional learning. 
In the same line, it is worth highlighting authors like Lavy [15] or Seatter and Ceulemans [20], whose studies put forward the need to use teaching methods that are able to promote constructivist learning, ensuring students' active participation in shaping their own knowledge. In this sense, peer tutoring and cooperative learning have proven to be effective strategies to make inclusion in Higher Education a reality.

Other research highlights the need to develop practices based on the Universal Design of Learning [16], so that students are respected in their ways of feeling, thinking and acting, to which can be added the importance of pedagogical strategies that give a voice to students in the teaching processes, such as research projects, problem-based learning and flipped classrooms [23].

On the other hand, another quantitative study focuses on studying professors' attitudes within the Attention to Diversity framework in the colleges of Art, Science, Administration, Law and Education at the University of Wisconsin (USA) [11]. The study aims at identifying significant differences and clarifying the potential relationship between the college in question and its way to approach diversity. The sample consisted of a total of 127 faculty members representative of each college on the campus, who completed a survey from a Likert scale. Results showed that most participating professors had a positive attitude towards difference, recognizing the importance of promoting the active participation of students with functional diversity in all aspects of college life. Likewise, the research found significant differences depending on the teaching, where professors of the College of Education had better expectations from students with difficulties than professors of any other college, probably motivated by their greater knowledge of educational inclusion and its curricular repercussions.

Bortolini, Oscar and Almeida [12], carried out an exploratory study to analyze university professors' attitudes towards the inclusion of students with functional diversity in the College of Philosophy and Science at the University of Marília (Brazil). The authors designed questionnaires that included questions related to the teaching experience with students with disabilities, main barriers and institutional support. They were sent to 162 university professors, although a total of 52 were finally completed. Among some of the most significant results, it is worth highlighting the favorable attitude of this professional sector towards educational inclusion, as they were committed to incorporating didactic adjustments to guarantee access to content for students with difficulties. However, most members of this research admitted that they would have had a better conceptual and methodological foundation to deal with diversity at university if they had been previously trained in educational inclusion. This is why they demanded life-long training on these issues, to reduce uncertainty about the best way to address each type of disability and to count with the necessary pedagogical resources and tools to do so.

The Technical University of Manabí (Ecuador) is a clear example of a pioneering institution when it comes to educational inclusion. A study was conducted there to develop a model to promote an inclusive pedagogical culture among the faculty members, with the participation of 39 teachers who had students with disabilities [13]. The context was diagnostically analyzed using the experimental method, and the model was designed based on this analysis. In addition to recognizing the systemic nature of educational processes, the model was based on the following aspects: students as the central axis of the teaching and learning processes, life-long training as key to a culture of inclusion at university, correspondence between the educational and instructive spheres and diversity as the core of didactic intervention. Once designed, the model was applied in the aforementioned university. Results showed that inclusive practices and initiatives increased, but most importantly, training workshops for university professors raised awareness of the relevance of attitudinal aspects (empathy, understanding, tolerance, active listening) to make inclusion in Higher Education possible.

With the purpose of implementing equity in the Chilean university system, a number of experts studied the implicit theories of university professors in the Biobío Region (Chile). They were interested in their notions of educational inclusion and the potential relationship between their theories and the implementation of inclusive teaching strategies [14]. 232 teachers participated in the research, selected with a non-probabilistic, intentional and convenience sampling. The study emphasized the relevance of implicit theories, as they are the foundation for curricular actions and decisions, the selection of didactic materials and the implementation of teaching and evaluation resources. Among the most outstanding results, faculty members showed confidence in the possibilities of university students with functional diversity, opting for participatory methodologies to ensure their leading role and the construction of significant learning. However, they did not feel directly responsible for the learning of these students, given the university barriers that make it difficult to implement certain projects to promote inclusion, such as the lack of specific resources and the lack of teacher training.

Furthermore, another quantitative research analyzed both the training of university professors in educational inclusion and the general knowledge and implications of inclusion in their teaching practice [17]. The sample was composed of 26 professors, 18 from a university located in the state of São Paulo and 8 located in the state of Minas Gerais, both in Brazil. It is worth mentioning that the participating professors admitted to lack direct responsibility for the learning of students with functional diversity, given the lack of specific training in this regard, which is required to identify and make decisions regarding 
the most effective teaching methods. In this sense the importance of having trained staff at university to whom to refer students with difficulties was noted, in order to receive psycho-pedagogical advice. They presented deficient notions about educational inclusion, so they demanded wide and diversified training. However, the faculty did not doubt the commitment and responsibility of their universities to implement an inclusive pedagogy, either by integrating these aspects in a cross-curricular way in the university curriculum, or by promoting training plans that allow an effective approach to diversity in the classroom.

Based on discussion groups, life stories and semi-structured interviews, other researchers developed a study in which 44 students with disabilities participated, with a twofold purpose: 1) to know professors' attitudes towards educational inclusion from the perception of students with functional diversity, and 2) to know which are the main barriers and difficulties encountered by these students during their learning process at university [18]. In relation to difficulties, the participating students acknowledged having to face physical barriers, in terms of infrastructures and spaces, but also curricular barriers, concerning contents and methodologies, as well as attitudinal barriers, being the latter the most significant ones. Attitudinal barriers were experienced due to the lack of confidence of some professors in their skills, together with their refusal to implement changes in their teaching practice to respond to diversity. They claimed that an attitudinal change in professors was needed, since this professional group is responsible, to a large extent, for students' self- confidence and their construction of learning at university. Educational support, curricular adaptations and methodologies that would give them prominence in the classroom together with the rest of students, are the necessary changes to overcome the attitudinal barriers they often encounter in the university context.

Along the same line and also based on discussion groups and in-depth interviews, it is worth highlighting another exploratory study [8], aimed at identifying the most significant barriers that students with functional diversity belonging to different Spanish universities face during their learning process. The study tried to identify the support given to these students on their way through university. 44 students participated voluntarily, accessed through the Diversity Service. The results showed that both the high ratio of classrooms and the lack of specific furniture adapted to their needs, prevented their positive inclusion in the university. Similarly, participants argued the need to have a true educational support and to overcome curricular rigidity as a way to favor their effective construction of learning. Regarding support, they positively valued the help received from the "collaborating student", that helps by taking notes in class or traveling around the campus.
To continue deepening the interest shown by the scientific community in the analysis of students' perception of their inclusion conditions in Higher Education, it is important to refer to a study that provided a general overview of inclusive processes in different Chilean universities, with the participation of all the students with functional diversity. [22]. Results showed interesting aspects, such as the fact that, while most surveyed students felt they were able to respond to university demands, they acknowledged to have been occasionally subject to discriminatory behavior. This aspect highlights the need to strengthen inclusive mechanisms and create awareness-raising bodies to promote diversity at university. In relation to professors' attitudes towards inclusion, the participating students also acknowledged having had involved and committed professors, defined as professionals who help make inclusion possible in the university context. Finally, it is worth emphasizing the value of inclusive programs at university, such as spaces for meeting and exchanging experiences.

In line with the contributions of previous authors, research and significant results, it can be noted that attention to diversity in the university setting requires the implementation of comprehensive approaches to education, with professors as the key to generate inclusive practices [21], all of which must be accompanied by a rethinking of teaching practice, since part of the students' academic results are derived from this practice, as well as offering an optimal educational response to students with functional diversity. Inclusion in Higher Education requires the presence of a coherent teaching staff, faithful to their principles and beliefs, who fully trust what they do and in view of the events must keep doing [24]. Professors should promote values and design conditions that lead students to access knowledge through experience and shared learning.

In accordance with the paradigm of educational inclusion, the educational responses provided by these professors will have a greater impact on the learning processes than students' characteristics, which poses the need to recognize teachers' responsibility in the learning process. In short, the aim is to find professors that focus not so much on transmitting content, but rather on rethinking their own practice $[25,26]$, with the purpose of identifying those didactic strategies that are useful to effectively respond to their students' demands, ensure the construction of relevant learning and promote values of respect for diversity, tolerance, self-fulfillment and equity [27].

Considering the above arguments and underlining the relevant role of professors in designing inclusive curricular structures, the main objectives of this study are as follows: (i) to analyze to what extent the teaching staff of the College of Education Sciences at the University of Malaga considers that their university must commit to making educational inclusion a reality; (ii) to find out their knowledge about inclusion, main functions and training 
received to make inclusion possible in their teaching practice; (iii) to know their opinion about the main repercussions of inclusive activities in their professional role; and (iv) to clarify which competencies are essential to work on educational inclusion at university.

\section{Materials and Methods}

The present study has followed a qualitative methodology based on an interpretive research paradigm of an inductive nature, as professors' attitudes have been interpreted from the content analysis of the interviews conducted. The study has examined some study variables, through evaluations and evidence expressed by the participating professors through in- depth interviews.

\subsection{Participants and Context}

The sample was composed of 56 professors (32 females and 24 males); from whom 29 taught in the degree in Primary Education and 27 in the degree in Social Education. The study was carried out in the College of Education Sciences at the University of Malaga (Andalusian region, Spain).

Professors from both degrees participated on a voluntary basis. To this end, they were selected from the faculty's directory on the website of the College of Education Sciences. They were contacted by email and sometimes by telephone, to arrange appointments (day and place) to conduct the interviews. In those contacts, the reason for the interview and the main objectives of the research were explained to them.

During the interviews, professors were encouraged to provide relevant data in line with the study objectives, bearing in mind the so-called "theoretical saturation criterion" [28]. The collection of evidence ended when new approaches and contributions stopped emerging.

\subsection{Data Collection Tool and Analysis Type}

Data was collected from semi-structured interviews conducted ad hoc with professors, using transcripts as empirical material for the research. Researchers asked questions in coherence with the objectives, in order for professors to be able to express their views in relation to the topic of research. The legitimacy of both the study and the interviews was made clear, together with the ethical and deontological aspects of the interviews.

Questions were written considering the current trends in the topic, hence the conceptual foundation of educational inclusion in Higher Education [3,9,19,29-31]. Specifically, the questions asked were as follows:

1) Do you think that the university has significantly changed in the last few years? If so, how does this change affect the teaching practice?

2) Should the university commit to making educational inclusion a reality? How?

3) What role do you think educational inclusion plays at university?

4) Do you have knowledge of educational inclusion and its impact on the university context?

5) To what extent do you think this influences your professional role?

6) Have you ever considered introducing changes in your practice to make educational inclusion possible? If so, which changes?

7) What competences are required to design inclusive curricular structures at university? Why do you think they are missing?

8) Have you received guidelines to implement educational inclusion in the university context?

9) Do you think that Higher Education facilitates life-long training in educational inclusion?

To get an overview of professors' attitudes, the content of the interviews was analyzed. The software Atlas.ti 8.04 (2013) was used to code and identify the transcripts, as an instrument to carry out the analysis of qualitative data, by connecting codes to textual excerpts, organizing and regrouping information and analyzing data in depth.

To define categories, the starting point was to limit the specific dimensions, in order to design a comprehensive framework for each professor, based on their testimony on the pedagogical practices of educational inclusion. Both text excerpts and evidence were key to analyze content in terms of categorization, review, results and conclusions. The category system was designed based on a deductive and inductive process. It was deductive because it started from a literature and conceptual review of the object of study. It was inductive because it was discussed and a consensus was reached among researchers to ensure that the necessary conditions to limit the category system were met [32]. Table 1 shows the dimensions used by the study data and the corresponding categories.

Table 1. Dimensions and categories used to analyze the interview excerpts.

\begin{tabular}{|c|c|}
\hline DIMENSIONS & CATEGORIES \\
\hline \multirow{2}{*}{$\begin{array}{c}\text { Educational inclusion in } \\
\text { the university context }\end{array}$} & \begin{tabular}{c} 
Inclusive university \\
\cline { 2 - 2 } Development of \\
Dedions of educational inclusion at \\
university
\end{tabular} \\
\hline $\begin{array}{c}\text { Higher Education } \\
\text { Training in educational } \\
\text { inclusion }\end{array}$ & $\begin{array}{c}\text { Previous knowledge of educational } \\
\text { inclusion }\end{array}$ \\
\cline { 2 - 2 } & Professor's role \\
\cline { 2 - 2 } & Commitment to the inclusive paradigm \\
\cline { 2 - 2 } & $\begin{array}{c}\text { Teacher training } \\
\text { Aptitudes to make inclusion in college } \\
\text { a reality }\end{array}$ \\
\hline
\end{tabular}

Source: Created by the author of this research.

Dimension 1: "Educational inclusion in the university context" (and the corresponding categories), analyzes the presence of the inclusive paradigm at university, starting 
from its functions, main changes experienced in recent years and repercussions on the teaching practice.

Dimension 2: "Development of educational inclusion in Higher Education" (and the corresponding categories), focuses on examining professors' knowledge of educational inclusion, whether they acknowledge the implication of this philosophy in their professional practice, and the responsibility that, in their view, should be assumed by Higher Education to implement an inclusive education respectful to diversity.

Dimension 3: "Training in educational inclusion" (and the corresponding categories), analyzes professors' initial and life-long training of issues related to educational inclusion, in addition to those aptitudes that are needed for teaching in coherence to the guidelines of an inclusive education respectful to diversity.

\section{Results}

Results have taken into account professors' most significant contributions, bearing in mind the categorization process and the set objectives. Next, some textual evidence will be provided and fully studied when the analysis of each category is completed.

The "Educational inclusion in the university context" dimension shows two categories that favor the study of two key issues: 1) professors' perception of university as a responsible space in promoting a culture linked to educational inclusion; and 2) the functions that must be carried out by Higher Education centers.

Table 2 shows a brief description of the categories with a selection of the most significant excerpts.

Table 2. Categories and interview excerpts.

\begin{tabular}{|c|c|}
\hline CATEGORY & EXCERPTS \\
\hline $\begin{array}{l}\text { Inclusive } \\
\text { university }\end{array}$ & $\begin{array}{l}\text { "University must be coherent to the principles } \\
\text { of inclusive education, which } \\
\text { involves addressing course subjects in a } \\
\text { cross-curricular way in those issues related to } \\
\text { social justice and emergency situations" }\end{array}$ \\
\hline $\begin{array}{c}\text { Functions of } \\
\text { educational } \\
\text { inclusion at } \\
\text { university }\end{array}$ & $\begin{array}{l}\text { "The inclusive paradigm must be present at } \\
\text { university as something visible and invisible, } \\
\text { to respond to diversity in a comprehensive } \\
\text { way. Working towards inclusion in university } \\
\text { aims to educate in values, as well as raising } \\
\text { awareness of the concept of diversity among } \\
\text { university students" }\end{array}$ \\
\hline
\end{tabular}

Source: Created by the author of this research.

In the "Inclusive university" category, it is worth mentioning that participating professors defined the university as a space committed to acquiring life-long competences, questioning and discussing the main social conflicts, in order to contribute to social transformation from professional practice. They consider this is the space where knowledge is life-long learnt, through dialogue and support with students, as the foundation for $21^{\text {st }}$ century universities.
They claim one of the main university changes in the last few years to be a greater sensitivity towards social issues. Teaching lectures are overcome to give way to innovative methods that favor the opening of university classrooms to the prevailing reality and its conflicts. In addition, interviewed professors claim that the dizzying changes that the university has gone through in recent years have had repercussions in their teaching practice, in the sense that they now face more demands to consolidate their professional career. All of which, and coming back to the axis of this research, poses difficulties in identifying how to best address educational inclusion at university. They admit that one of the challenges faced by professors is to promote functional learning, in order to teach effectively and to continuously seek the best way to link theory to practice.

Regarding the "Functions of educational inclusion at university" category, the interviewed faculty claims it is about raising awareness in aspects related to diversity among university students, considering that diversity is inherent to each one of us and a key to educate in values in the university context. Likewise, they urge Higher Education centers to commit to educational inclusion, integrating these issues cross-curricularly into the curriculum, and encouraging training plans on diversity.

As for the "Development of educational inclusion in Higher Education" dimension, the study shows three categories that collect information from professors' previous knowledge on this subject, their degree of commitment and responsibility in implementing the philosophy of educational inclusion at university, and the repercussions that this, in their view, has on their professional practice. Table 3 shows some of the most representative interview excerpts related to these categories.

Table 3. Categories and interview excerpts.

\begin{tabular}{|c|c|}
\hline CATEGORY & EXCERPTS \\
\hline $\begin{array}{l}\text { Previous } \\
\text { knowledge of } \\
\text { educational } \\
\text { inclusion }\end{array}$ & $\begin{array}{l}\text { "Educational inclusion reflects the social } \\
\text { evolution in the attention to students with } \\
\text { functional diversity, seeking solidarity } \\
\text { learning spaces" }\end{array}$ \\
\hline Professor's role & $\begin{array}{l}\text { "Educational inclusion must be present in } \\
\text { the course subjects, rethinking } \\
\text { methodologies for students with barriers in } \\
\text { their learning to be able to overcome them" }\end{array}$ \\
\hline $\begin{array}{c}\text { Commitment to } \\
\text { the inclusive } \\
\text { paradigm }\end{array}$ & $\begin{array}{l}\text { "Universities must commit to inclusion. As } \\
\text { professors, we must offer personalized } \\
\text { attention, resorting to innovative } \\
\text { methodologies, such asservice } \\
\text { learning" }\end{array}$ \\
\hline
\end{tabular}

Source: Created by the author of this research.

In the "Previous knowledge about educational inclusion" category, participating professors highlighted that this paradigm was designed in line with the changes, in society in general and in education in particular, that have been implemented in the last few years, seeking to promote educational spaces in which students with functional 
diversity can develop their full potential. Similarly, by pointing that educational inclusion reflects an important change in social mentality towards diversity, they implicitly acknowledge that educational inclusion is the necessary path to reach social inclusion.

With regard to repercussions from educational inclusion in professors' role and commitment to implement inclusive educational structures, the content analysis of the interviews shows that professors take responsibility in this field, selecting methodologies that ensure the full participation of their students in the learning process, overcoming difficulties, increasing motivation and developing shared learning experiences. In this sense, they stress the need to resort to service learning as one of the most beneficial pedagogical tools.

In the last dimension: "Training in educational inclusion", the categories tried to find out the initial and life-long teacher training in this field, as well as the aptitudes that are considered essential to teach according to educational inclusion. Table 4 shows some of the most representative excerpts for these questions.

Table 4. Categories and interview excerpts.

\begin{tabular}{|c|l|}
\hline CATEGORY & \multicolumn{1}{|c|}{ EXCERPTS } \\
\hline \multirow{5}{*}{ Teacher Training } & $\begin{array}{l}\text { "(..) I have not attended courses } \\
\text { offered by the Staff Service of the } \\
\text { University of Malaga. To To } \\
\text { compensate, I participate in } \\
\text { conferences on } \\
\text { these topics. In my initial training, } \\
\text { there was talk of 'school integration", } \\
\text { but not of educational inclusion" }\end{array}$ \\
\hline $\begin{array}{c}\text { Aptitudes to make } \\
\text { inclusion in } \\
\text { college a reality }\end{array}$ & $\begin{array}{l}\text { "Inclusion must be worked on in all } \\
\text { university degrees. It takes training } \\
\text { and commitment, research and } \\
\text { rubbing shoulders with experts" }\end{array}$ \\
\hline
\end{tabular}

Source: Created by the author of this research.

In the "Teacher training" category, professors admitted that they have not received specific training on inclusion and its repercussions at university, trying to compensate for this "lack of training" by attending conferences and workshops in topics related to educational inclusion. Likewise, they have observed a terminological and ideological shift in this topic in their initial training, as they originally worked around the so-called "school integration" concept back then.

Finally, in the "Aptitudes for inclusion at university to become a reality" category, professors point the importance of accessing continuous and diversified training, together with interest and true commitment, and consider motivational variables to have an outstanding weight. They argue that the necessary competences for inclusion at university to become a reality must go hand in hand with the development of research tasks, highlighting the importance of synergies with experts, all of which contributes to professional training and development.

\section{Discussion and Conclusions}

The overall purpose of this study was to find out professors' pedagogical perceptions of educational inclusion in the College of Education Sciences at the University of Malaga. The most relevant findings in relation to each of them will be discussed.

With regard to the commitment that, in view of the teaching staff, universities must make to educational inclusion, professors consider that current universities should be held fully responsible for inclusion, not only in the degrees of Education, but in all university degrees. Commitment is key in the construction of teaching that promotes innovation and quality as inclusive responses adapted to personal and collective learning needs.

Regarding their knowledge of this educational philosophy and its main functions, results showed that professors define the inclusive paradigm as a way of educating in values and attitudes of solidarity, tolerance and respect to diversity, admitting that diversity enriches us and shapes our personal identity, in line with a fully democratic and prosocial professional development.

As the most significant repercussions of inclusive practices in the professor's role, it is worth highlighting the need to reformulate traditional teaching practices, in order to identify methodologies that can guarantee access to students learning from all over the world, including those with difficulties.

In particular, competences linked to affective, social and emotional variables are considered essential to make inclusion at university possible, as they account for the necessary sensitivity to address, in a cross-curricular way, any issue related to educational inclusion at university. In this sense, both initial and life-long training are regarded as essential instruments to implement educational inclusion in the university context, together with interdisciplinary work groups and the promotion of research on those pedagogical practices that are key to design an inclusive university.

Once the research objectives have been analyzed, it is important to conclude by discussing relevant aspects of the main results.

The interviewed professors believe that the main challenges of current university education consist of promoting values and aptitudes, developing competencies for professional development and addressing topics adapted to change and social evolution. To this end, it can be noted that $21^{\text {st }}$ century universities are a reflection of social transformation, where professors are many times forced to teach in environments marked by perplexity and institutional pressure. As several authors have stated [33, 34], this involves overcoming traditional academic models in order to offer a humanistic education, linked to the current world crisis.

Considering that diversity is inherent to every one of us, the interviewed professors highlight the importance of its inclusion in Higher Education, admitting that this would 
affect their professional role, as it would foster an education that promotes values and aptitudes of respect to diversity and appreciation of differences. These approaches are discussed in other studies, too $[8,11,12,16,18,27,35]$, which argue that professors must definitely undertake a teaching practice in which students with functional diversity have a place, identifying their main difficulties and trying to respond to them in the most effective way possible.

Furthermore, professors consider training very relevant in the context of educational inclusion, as a way to overcome uncertainties when seeking the best way to address diversity in Higher Education. This data is relevant in other research studies, where the value of training is emphasized as a variable that helps to improve teaching aptitudes towards educational inclusion $[8,17,19,22,23,29,30,36]$.

As for methodologies for educational inclusion at university, the study acknowledges the need to resort to participatory and innovative methods, in order to give students a leading role in their learning process. This line is also reflected in further studies [15,21,37-39], which consider that one of the factors that contributes to implement inclusion at university is the use of methods that involve students in the classroom (promoting cooperative learning, role-plays, case studies, and so on), thus ensuring their peer interaction. Service learning has been mentioned as an example for methodological tools that are committed to educational inclusion, which is supported by further research [40], in which service learning is defined as a type of experiential education for improving the society. This is a significant aspect to approach educational inclusion at university.

Once the most relevant aspects of this research have been discussed, the need to conduct studies like this is incontestable.

However, the research has encountered some limitations that should be pointed out: contributions came only from professors in the College of Education at the University of Malaga. This is why it would be enriching to continue deepening in the subject, and have professors from other degrees participating in the study, in order to compare the way the paradigm of educational inclusion can be implemented in different degrees at the University of Malaga.

Moreover, it would be very interesting to count with students' narratives, especially those with some kind of functional diversity. This element is key insofar as it would allow us to contrast barriers and opportunities in the implementation of educational inclusion in a university setting.

Similarly, the use of interviews as the only instrument to respond to the objectives set by the study accounts for yet another limitation. Further research is needed, using quantitative data collection techniques, in order to carry out a triangulation of the results.
This research study concludes that diversity is an invaluable value in education and, as such, it needs to be respected. The respect to diversity must cover all areas of education, forming alliances with all members of the university community, so that inclusive education becomes real, purposeful, responsible and committed.

\section{REFERENCES}

[1] A. Lombardi, C. Murray and J. Kowitt. Social Support and Academic Success for College Students with disabilities: Do relationship types matter? Journal of Vocational Rehabilitation, Vol. 44, 1-13. 2016.

[2] M. Sandoval, C. Simón and G. Echeita. A critical review of education support practices in Spain. European Journal of Special Needs Education, Vol. 34, No. 4, 441-454. 2019

[3] N. Melero, A. Moriña and V.H. Perera, V.H. Acciones del profesorado para una práctica inclusiva en la universidad. Revista Brasileira de Educação, Vol. 24, 1 -19.2019

[4] P. Arnaiz, R. De Haro and C.M. Azorín. Redes de apoyo y colaboración para la mejora de la educación inclusiva. Profesorado. Revista de Currículum y Formación del Profesorado, Vol. 22. No. 2, 29 -49. 2018

[5] K. Björnsdóttir. Belonging to higher education: inclusive education for students with intellectual disabilities. European Journal of Special Needs Education, Vol. 32, No. 1, 125-136. 2017

[6] R. Carballo, A. Cotán and Y. Spínola. An Inclusive Pedagogy in Arts and Humanities University Classrooms: What faculty members do. Art and Humanities in Higher Education, 1-21. 2019

[7] M.E. Martins, M.L. Morges and T. Gonçalves. Attitudes towards inclusion in Higher Education in a portuguese university. International Journal of Inclusive Education, Vol. 22, No.5, 527-542. 2018

[8] A. Moriña and V.H. Perera. Inclusive Higher Education in Spain: Students with Disabilites Speak Out. Journal of Hispanic Higher Education, Vol. 00, No. 0, 1-17. 2018

[9] A. Moriña. The keys to learning for university students with disabilities: motivation, emotion and faculty-student relationships. PLoS ONE, Vol.14, No. 5, 1-15. 2019

[10] M. Norris, J. Hammond, A. Williams and S. Walker. Students with specific learning disabilities experiences of Pre-registration Phisioterapy Education: A qualitative study. BMC Medical Education, Vol. 20, No.2, 1-11. 2020

[11] S. Becker and J. Palladino, J. Assessing faculty perspectives about teaching and working with students with disabilities. Journal of Postsecundary Education and Disability, Vol. 29. No.1, 65-82. 2016

[12] R. Bortolini, F. Oscar and I. Almeida. Inclusão no ensino superior: a percepção de docentes de una instituição publica do interior do estado de São Paulo. Psicología Escolar e Educacional, SP, 127-134. 2018

[13] I.M. Fernández -Fernández, V. Véliz -Briones and A.I. 
Ruiz-Cedeño. Hacia una cultura pedagógica inclusiva. Experiencias desde la práctica universitaria. Revista Electrónica Educare, Vol. 20. No. 3, 1 -15.2016

[14] C. Herrera-Seda, C.P. Pérez -Salas and G. Echeita. Teorías implícitas y prácticas de enseñanza que promueven la inclusión educativa en la Universidad. Instrumentos y Antecedentes para la Reflexión y Discusión. Formación Universitaria, Vol. 9, No. 5, 49-64. 2016

[15] S. Lavy. Who benefits from group work in Higher Education? An attachment theory perspective. Higher Education, Vol. 73, 175- 187. 2017

[16] G. Lawrie, E. Marquis, E. Fuller, T. Newman, M. Qiu, M. Nomikoudis, F. Roelofs, and L. Van Dam. Moving Towards Inclusive Learning and Teaching: A Synthesis of Recent Literature. Teaching \& Learning Inquiry, Vol. 5, No.1, 1-13. 2017

[17] F.V. Mafra, E. Gomes, P. Cezar de Faria, D. Lozano and C. Gomes, C. Training of university professors and their meaning for inclusive education. Educ. Pesqui., São Paulo, Vol. 44, 1 -12. 2018

[18] V.M. Molina, V.H. Perera, N. Melero, A. Cotán and A. Moriña. The role of lecturers and inclusive education. Journal of Research in Special Educational Needs, Vol. 16, 1046-1049. 2016

[19] A. Moriña. Faculty members who engage in inclusive pedagogy: Methodological and effective strategies for teaching. Teaching and Higher Education, 1-16. 2020

[20] C.S. Seatter and K. Ceulemans. Teaching Sustainability in Higher Education: Pedagogical styles that make a difference. Canadian Journal Higher Education, Vol. 47, No. 2, 47-70. 2017

[21] S. Veitch, S., K. Strehlow, and J. Boyd. Supporting University Students with Socially Challenging Behaviours Through Professional Development for Teaching Staff. Journal of Academic Language \& Learning Vol.12, No.1, A156-A167. 2018

[22] G.P.Villafañe, A.A. Corrales and V.J. Soto. Estudiantes con discapacidad en una universidad chilena: desafíos de la inclusión. Revista Complutense de Educación, Vol. 27, No. 1, $353-372.2016$

[23] L. Altemueller and C. Lindquist. Flipped Classroom Instruction for Inclusive Learning. British Journal of Special Education, Vol. 44. No.3, 341-358. 2017

[24] M. J. Alcalá del Olmo and J.D. Gutiérrez -Sánchez. (2020). El Desarrollo Sostenible como reto pedagógico de la Universidad del Siglo XXI. Anduli. Revista Andaluza de Ciencias Sociales, Vol. 19, 59-80. 2020

[25] A. Moriña. Inclusive education in higher education: challenges and opportunities. European Journal of Special Needs Education, Vol. 32, No.1, 3-17. 2017

[26] A. Moriña, and A. Cotán. Educación Inclusiva y Enseñanza Superior desde la Mirada de Estudiantes con Diversidad
Funcional. Revista Digital de Investigación en Docencia Universitaria, Vol. 11, No.1, 20-37. 2017

[27] B. Manzano-García and M. Tomé -Fernández. The Inclusive Education in Europe. Universal Journal of Educational Research, Vol. 4, No. 2, 383-391. 2016

[28] U. Flick. The sage Handbook of Qualitative Data Collection, Sage Reference, London, 2018.

[29] B.S.S. Hong. Qualitative Analysis of the barriers college students with disabilities experiences in higher education. Journal of College Student Development, Vol. 56, No. 3, 209-226. 2015

[30] A. Moriña, R. López-Gavira and V.M. Molina. What if we could Imagine an Ideal University? Narratives by Students with Disabilities. International Journal of Disability, Development and Education, Vol. 64, No. 4, 353--367. 2016.

[31] O. Lipka, M. Khouri and M. Shecter-Lerner. University faculty attitudes and knowledge about learning disabilities. Higher Education Research \& Development, Vol. 38, 1-15.

[32] B.G. Glaser and A.L. Strauss. The discovery of Grounded Theory. Strategies for qualitative research, Routledge, London, 2017.

[33] A. Magalhães and A. Veiga. Reconfiguring education and research in the European Higher Education Area. Revista Lusófona de Educação, Vol. 42, 11 -25. 2018

[34] M. Ruiz-Corbella and E. López-Gómez. La misión de la universidad en el siglo XXI: comprender su origen para proyectar su futuro. Revista de la Educación Superior, Vol. 48, No.189, 1-19. 2019

[35] P. Kindelan, E. Ayuga-Têlez, D. Martń and M.Valiente. Perception of Faculty of the Bologna Process at a Spanish Technical University: A perspective of Change and Improvement. European Education. Vol. 51, 51-70. 2019.

[36] C.L. Schelly, P.L. Davies and C.L. Spooner. Student Perceptions of Faculty Implementation of Universal Design for Learning. Journal of Postsecondary Education and Disability, Vol. 24, No.1, 17-30. 2011

[37] J.P. Beaudoin. Introduction to inclusive teaching practices. Centre for University Teaching, Teaching and Learning Support Service, Otawa, 2013.

[38] I. Coskun and C. Eker. The Effect of Teaching Activities Done by Using Activity Based Posters on the Students' Academic Achievements, Retention Levels in Their Learning. Universal Journal of Educational Research, Vol. 6, No. 4, 585-597. 2018.

[39] D. Guasch and J. Hernández. Guía para implementar el Universal Instructional Design - UID (diseño instruccional universal) en la universidad, Observatorio Universidad y Discapacidad, Barcelona, 2012.

[40] H. Opazo, P. Aramburuzabala and R. Cerrillo. A review of the situation of service-learning in higher education in Spain. Asia- Pacific Journal of Cooperative Education, Vol. 17, No.1, 75-91. 2016 